University of Warwick institutional repository: http://go.warwick.ac.uk/wrap This paper is made available online in accordance with publisher policies. Please scroll down to view the document itself. Please refer to the repository record for this item and our policy information available from the repository home page for further information.

To see the final version of this paper please visit the publisher's website. Access to the published version may require a subscription.

Author(s): Shaun Breslin

Article Title: Power and production: rethinking China's global economic role

Year of publication: 2005

Link to published version: http://dx.doi.org/

10.1017/S026021050500673X

Publisher statement: None 


\title{
Power and production: rethinking China's global economic role
}

\author{
SHAUN BRESLIN*
}

When Gerry Segal asked 'Does China Matter?' in 1999, his answer was an unequivocal 'no':

the country that is home to a fifth of humankind is overrated as a market, a power, and a source of ideas. At best, China is a second-rank middle power that has mastered the art of diplomatic theater: it has us willingly suspending our disbelief in its strength. In fact, China is better understood as a theoretical power - a country that has promised to deliver for much of the last 150 years but has consistently disappointed. A fter 50 years of M ao's revolution and 20 years of reform, it is time to leave the theater and see China for what it is. Only when we finally understand how little China matters will we be able to craft a sensible policy toward it. ${ }^{1}$

'D oes China $M$ atter?' was largely intended to be an antidote to what he perceived as the unrealistic assessments of Chinese power that were emanating from the $U$ nited States at the time. 'Is China as powerful as some people are making it out to be?' would have been a more fitting question and title, but would probably have had significantly less impact.

The question of whether $C$ hina is as powerful as some analyses suggest is also the starting point of this article. The growth of the Chinese economy in general, and the growth of Chinese exports in particular, have led to a growing strand of literature assessing the shifting balance of power in the global political economy. For some, China's rise is at the expense of J apan's regional role; 2 for others, China is becoming an economic superpower that will come to challenge the economic dominance of the USA. But while China is clearly important and significant, does this equate with power?

Understandings of Chinese power in the global political economy are often overstated because political analyses of economic relations still rely too strongly on conceptions of bilateral relations between nation states. By considering the nature of post-F ordist production and globalisation, different conceptions of the location of power emerge that are not necessarily territorially bound. Instead they draw attention to the role of supra or transnational 'commodity driven production networks' 3 that have done much to generate $C$ hinese economic growth in recent years.

* This article was written whilst I was Visiting Professor at City U niversity of H ong K ong, and I am grateful to CityU for their support.

1 G erald Segal, 'D oes China M atter?', Foreign Affairs. 78:5 (1999), p. 24. This was an extended version of a paper first published as G erald Segal, 'Still a Fragile Power', New Political Economy, 3:3 (1998), pp. 442-4. The question has been revisited in Barry Buzan and R osemary F oot (eds.), Does China Matter?: A Reassessment (London: R outledge, 2004).

2 See J ean-Pierre L ehmann, 'China rising, Japan falling', South China Morning Post, 29 N ovember 2003; and J ean-Pierre L ehmann. 'A sia's two giants will trade places as fortunes change', South China Morning Post, 6 September 2002.

3 Gary Gereffi and M iguel K orzeniewicz (eds.), Commodity Chains and Global Capitalism (W estport, CT: Praeger, 1993). 
Where Chinese government elites do have power is in the way that they have inserted parts of the Chinese economy into the global economy. Increasing the attraction of China as a low-cost production platform to produce exports to external markets has resulted in job losses elsewhere, distorted and perhaps even undermined the developmental strategies of other states, and led to a reconfiguration of the East A sian political economy.

\section{Competing visions of $\mathrm{C}$ hina}

F or some observers, China is the engine of growth in the global economy, or at least an emerging power well on the way to becoming a global superpower ${ }^{4}$ that threatens to reconfigure the global political economy and will eventually result in China's emergence as the global hegemon. ${ }^{5}$ It is already the second biggest economy in the world 6 and is predicted to overtake the U S in 2020 or 2041 or 2050 or some time this century, and overtook the USA as the single biggest recipient of non-stocks and shares foreign direct investment (FDI) in 2002. China is the fourth largest trader in the world, and has massive foreign currency reserves (second only to Japan). Economic superpower status is well on the way, with for some, confrontation and conflict with the USA as the existing superpower an inevitable conclusion. ${ }^{7}$

For others, the Chinese economy is in crisis, needing a miracle to postpone economic and social collapse. ${ }^{8} \mathrm{D}$ espite continued economic growth and the increased living standards of many Chinese, there is rural poverty that is exacerbated by harsh and often corrupt excising of taxes, endemic corruption in general, large and growing levels of urban unemployment, an unprecedented level of still growing inequality, mass migration from the countryside to the cities, staggering levels of debt within the financial system, and the rapid deterioration of the environment.

These conflicting interpretations can partly be reconciled by doing some maths. W ith a population of over $1.3 \mathrm{bn}$, each person does not have to have great individual wealth to generate a large overall economy. Per capita income did not break the U S\$1,000 barrier until 2003, leaving China outside the top 100 richest economies in per capita terms whilst the seventh biggest economy in the world. Even using PPP calculations to take into account the non-market elements of the Chinese economy and exchange rate distortions, a per capita figure of U S\$4,672 still leaves China 114th in a league table of per capita wealth, whilst second in the table of the world's largest economies. And when you start from a very low base, then it is relatively easy to generate high levels of growth - if you produce one tractor one year and two the next, you have 100 per cent growth, but you still only have three tractors. So even after two decades of double-digit growth, China's per capita income is still only around half of R ussia's, whichever form of calculation is used.

${ }^{4}$ F or example, William Overholt, The Rise of China: How Economic Reform is Creating a New Superpower (N ew Y ork: N orton, 1993); G eoffrey M urray, China: The Next Superpower: Dilemmas in Change and Continuity (Basingstoke: Palgrave/M acmillan, 1998); and Cesar F elipe Bacani, The China Investor: Getting Rich with the Next Superpower (N ew J ersey: J ohn W iley, 2003).

5 Steven W. Mosher, Hegemon: China's Plan to Dominate Asia and the World (San F rancisco, CA: Encounter, 2001).

6 U sing Purchasing Power Parity (PPP) calculations.

7 R ichard Bernstein and R oss M unro, The Coming Conflict with China (N ew Y ork: Vintage, 1998).

${ }^{8}$ Gordon Chang, The Coming Collapse of China (N ew Y ork: R andom H ouse, 2001). 
These different interpretations can also partly be reconciled by considering the growth strategy that C hina's leaders have pursued. A ttracting investment to produce exports has been the major source of economic growth since the mid 1990s. As a result, China's international economic profile and impact has significantly increased. But at the same time, the domestic economy hardly grew at all between 1996 and 2002. D ouble digit growth over two decades has been accompanied by ever increasing unemployment - indeed, even as the Chinese economy was growing at 12 per cent in the first quarter of 2004 leading to fears that the economy was overheating, unemployment in China was actually increasing. ${ }^{9}$

So in some respects, the vision of China as a global economic power can be reconciled with visions of continuing and even worsening domestic economic dislocations. But not wholly so. These conflicting interpretations of China are also explained by the different focuses, epistemologies, and methodologies of observers, academics and policy analysts. A the risk of oversimplification, there is a dichotomy between those who study China from the inside out, and those who emphasise international relations, typically conceiving of the nation state as the basic unit of analysis, conceiving of the state as a unitary actor and largely accepting the ontological separation of the domestic from the international.

Specialists on the internal domestic situation, those who look at China from the inside out, are drawn towards the very real social, economic and political problems that exist within China. The external international dimension is not ignored - far from it. It is considered in terms of its impact on the reconfiguration of the domestic political economy, the way in which discourses of international relations and nationalism are used as a tool of domestic legitimacy and social control, and the extent to which domestic political considerations constrain the actions of the $C$ hinese leadership on the international arena.

Those who study from the outside in, largely tend to be the prophets of Chinese power-particularly those who work in policy-related institutions and disciplines who study the implications of China in and for other countries. In this respect, where you are writing from (or for), is also important. Within East A sia, the growth of the Chinese economy has had a profound impact on both the structure of the regional political economy, and on the developmental trajectories of individual regional states. The conception of China as a major power is also much more evident in the U S than it is in Europe. Indeed, the vast majority of the literature predicting a future Chinese superpower challenging US power emerges from writers based in the US, largely intended to influence U S policymakers. In discussing why this is the case with colleagues based in the US, the answer is frequently that Europeans have yet to fully understand the real challenge that China poses.

$M$ aybe so. It is certainly true that China plays a much more important role in domestic politics in the US than it does in European states. For many years the theatre of the vote over whether to extend M ost F avoured N ation ${ }^{10}$ status to China provided an annual opportunity to debate the wisdom of engaging China, and the implications of China's resurgence for the U S. W ith the decision to extend permanent normal trading relations in 1999 to pave the way for China's WTO entry, the annual opportunity to debate $\mathrm{C}$ hina has disappeared. But debate continues, particularly in

\footnotetext{
9 Jim Y ardley, 'China faces stiff challenge to create work', International Herald Tribune, 29 M ay 2004.
}

$10 \mathrm{~N}$ ow called N ormal Trade R elations. 
the run up to a presidential election. For example, Chris $\mathrm{N}$ elson argues that 'the issues of job loss and outsourcing have a resonance now that they haven't had before. A nd the D emocrats have linked China in the minds of voters to those things'. These comments followed the publication of a 2004 poll which showed that 72 per cent of those surveyed thought that job losses to China were a serious or very serious problem, and that 60 per cent of respondents 'have doubts' over President Bush's policy towards trade with China. ${ }^{11}$

But perhaps the main reason that the rise of China has more prominence in the US than in Europe is differing conceptions of what can be done to prevent or shape China's rise. When the U K F oreign A ffairs Committee debated U K relations with China in 2000, the debate over whether to engage or contain C hina was a non-debate. There was an acceptance that ' $O$ ur influence can only be at the margins', ${ }^{12}$ and that the UK simply did not have the ability to have any considerable impact on what happened in China. By contrast, there is a conception in the U S that the actions of the U S government can influence what happens in China - particularly in economic terms. The sheer importance of the US market for a China all but dependent on export growth as an engine of overall domestic economic growth means that discussions of the nature of Chinese economic power are not just of academic interest, but could and should influence U S policy towards China.

It is not just that a new power is rising to challenge U S supremacy, but the nature of the state that is providing this new challenge. On one level as one of the R epublican representatives who opposed extending PNTR to China has put it, 'the Chinese government is a brutal regime'. ${ }^{13}$ The well documented human rights abuses in China mean that the West should not be engaging China, but using whatever means possible to force change. Worse still, by engaging China economically, and facilitating the growth of the Chinese economy through international economic relations, the U S and the W est in general might actually be strengthening the power of the authoritarian CCP leadership. There is also concern about how a newly powerful China will behave in the international system. Johnston has characterised China as a 'dissatisfied power' that does not ascribe to dominant international norms. D espite official Chinese rhetoric stressing China's commitment to stability in the international system and an acceptance of the status quo, it is a state that will do what it can to reshape the global order to fit its own priorities as soon as it has the power to do so. ${ }^{14}$

While this might explain different conceptions of what to do about the rise of China, it doesn't explain why China is deemed to have economic power in the first place. Here, we need to focus on conceptions of the structural power of the Chinese market, the way in which Chinese economic growth is reconfiguring the global distribution of finances and trade, the impact of Chinese exports on growth and jobs elsewhere, and Chinese control over production in key economic sectors.

${ }^{11}$ Edward A Iden and J ames H arding, 'Bush's China stance hands K erry a big stick', Financial Times, 30 A pril 2004.

12 F oreign A ffairs Committee, Tenth Report, Session 1999-2000: Relations with the People's Republic of China (N orwich: H M SO, 2000), para. 108.

${ }^{13}$ F rank W olf, 'Excerpts: R ep. W olf Says China W on't L et U .S. M onitor R ights', Office of International Information Programs, U S D epartment of State, 18 J uly 2003, 〈http://usinfo.state.gov/ regional/ea/uschina/prcwolf.htm〉.

${ }^{14} \mathrm{~F}$ or a comprehensive overview of the debates over whether China is a 'status quo' power or not, see A lastair Iain J ohnston, 'Is China a Status Quo Power?', International Security, 27:4 (2003), pp. 5-56. 


\section{The structural power of the $\mathrm{C}$ hinese market}

In developing his conception of the 'new constitutionalism', Gill argues that the U S government uses the structural power of the size of its market to force change on other countries while not reciprocating with corresponding liberalisation of the US economy in order to benefit U S based economic interests. ${ }^{15}$ This conception provides an interesting way of thinking about the process of negotiating China's entry into the WTO. Indeed, I have argued elsewhere that the need to secure access to the U S market was an important (though not the only) reason why Chinese negotiators accepted WTO membership criteria far exceeding the obligations of previous members - and even 'developed country' members. ${ }^{16} \mathrm{H}$ ere, the question is whether we can think in terms of the structural power of the Chinese market.

It is certainly true that virtually every business that has tried to locate in China and/or sell in the Chinese market has faced massive obstacles. G overnment restrictions on who can do business in which sectors were specifically designed to protect domestic producers from international competition in order to maintain production, profitability and jobs. At the same time, government officials at the national and local levels provided support for domestic exporters, and also created a remarkably liberal internationalised export regime to encourage FDI to produce exports.

$M$ aintaining a relatively closed and protected domestic market whilst encouraging exports to the lucrative markets of the developed world is not a uniquely Chinese strategy. Indeed, the Chinese strategy was in large part inspired by the success of other export-orientated developing states in East A sia. But times have changed. The geostrategic Cold W ar agenda that allowed J apan, South K orea and Taiwan unprecedented access to the $U \mathrm{~S}$ market whilst not reciprocating with domestic market access has gone ${ }^{17}$ - and even if it were still in place, then China would be on the wrong side of the Cold War divide. So a large element in perceptions of the Chinese economy and China's global economic role stems from a conception of China unfairly manipulating the rules of the global economy - the idea that China 'cheats'. 18

China's WTO entry was expected to remove such government protection, and create the opportunity for foreign companies to succeed in the Chinese market. A nd indeed some foreign companies, particularly auto producers, made significant gains relatively quickly in the wake of WTO entry. However, despite initial enthusiasm over the pace of liberalisation, subsequent assessments have been more cautious. In the annual report to Congress, the USTRO noted that WTO implementation 'lost a significant amount of momentum' in 2003, and this could no longer just be put down to 'start up problems'.19 Charles F reeman, D eputy A ssistant U S Trade Representative, similarly argued that:

15 Steven Gill, 'N ew Constitutionalism, Democratisation and G lobal Political Economy', Pacifica Review, 10:1 (1998), pp. 23-38.

16 Shaun Breslin, 'R eforming China's Embedded Socialist Compromise: China and the WTO', Global Change, Peace \& Security, 15:3 (2003), pp. 213-29.

17 Bruce Cumings, 'The Origins and D evelopment of the $\mathrm{N}$ ortheast A sian Political Economy: Industrial Sectors, Product Cycles, and Political Consequences', in F red D eyo (ed.), The Political Economy of the New East Asian Industrialism (N ew Y ork: Cornell U niversity Press, 1987), pp. 44-83.

18 The word used by Lindsey Graham, R epublican Senator for South Carolina. D avid Barboza, 'T extile industry seeks trade limits on Chinese', New York Times, 25 J uly 2003.

19 U S Trade R epresentative Office, 2004 Report to Congress (U S-China Economic and Security R eview Commission, J une 2004). 
in a number of different sectors, including some key sectors of economic importance to the U nited States, some Chinese ministries seemed to spend as much energy avoiding China's WTO obligations as living up to them. ... and intervention by $C$ hinese government officials in the market is largely unchecked. ${ }^{20}$

\section{Constructing visions of China}

Complaints about the lack of WTO-related reform are in part inspired by the impact of the growth of Chinese exports, an issue we will return to later. But they are also inspired by frustration at the continued inability to gain access to the $C$ hinese market. The image of $C$ hina as a great economic power with tremendous wealth emerges from the 'Shanghai phenomenon'. V isitors to China - not least government officials and business leaders - typically only visit the major cities. A nd if you go to Shanghai, you are presented with a vision of a vibrant city with a new and modern skyline and increasing commercial and personal prosperity. Add this to double-digit growth figures and it is easy to construct a vision of China that belies the reality of the daily life of most Chinese:

These days China presents the image of success. Chinese leaders tell us that they're doing a great job, and they give us statistics that back them up. F oreign (non-Chinese) experts assure us that the People's R epublic has a bright future. We can all look at the potential of China and become giddy. We extrapolate, multiply, and then let our imaginations run wild.21

The growth of the $C$ hinese economy has been important in securing new markets and profits for some companies. But it is what the Chinese economy might become - its potential - that still dominates much consideration and policy. Returning to the debate over renewing M F N to C hina, 300 corporate leaders asked the President not to obstruct the 'large potential benefits'22 of extending M FN to China in 1993.23 Similarly, in the Parliamentary report on UK relations with China in 2000, submissions from individual business groups and business organisations typically pointed to the potential of the Chinese market.

The emphasis on the potential of the $C$ hinese market largely stems from a desire to influence government policy. In the U S case, if M F N were not to be renewed, then U S companies would not be eligible for export credit and investment guarantees from the US government. For major corporations like Boeing, Chrysler, and General $M$ otors, these guarantees were essential for their growing relationship with China. Given that EU states in particular were perceived as being less interested in human rights in China than developing commercial contacts, if the U S took a moral stance, then U S companies would simply lose out to their E uropean competitors. In the U K case, in discussing whether UK policy disadvantages UK companies at the expense of E uropean competitors, J ames Richards on behalf of R olls R oyce argued that:

${ }^{20}$ Charles F reeman, 'W itness T estimony: U S-China Trade', Preparations for the J oint Commission on Commerce and Trade Subcommittee on Commerce, Trade, and Consumer Protection, $31 \mathrm{M}$ arch 2004.

${ }^{21}$ G ordon Chang, 'E vidence to the H ouse U S-China Commission', 2 A ugust 2001, 〈http://www.uscc.gov/tescha.htm〉.

22 R obert Bernstein and Richard Dicker, 'H uman Rights First', Foreign Policy, 94 (1994), pp. 44-5.

${ }^{23} \mathrm{M}$ ark R oden, 'The International Political E conomy of Contemporary U S-China R elations', Ph.D thesis, D epartment of Politics, U niversity of Sheffield, 2000, p. 87. 
What is important for us, given the extremely competitive nature of the market in China and the fact that export credits are available for our competitors, is that we should be no worse off, that we should receive equivalent treatment, because without it our business in China would certainly be undermined. ${ }^{24}$

F or critics of government policy such as A mnesty I nternational, helping nationallybased companies succeed in China has resulted in wider change in diplomatic policy towards China. F or example, a parliamentary report in the U K in 2000 was in large part commissioned because of fears that the UK government had decided to draw back on criticisms of China's human rights regime and had moved away from an ethical foreign policy in an attempt to help U K companies win contracts in China. In the $U \mathrm{~S}$, the extension of M F N to China under Clinton was similarly taken as a sign that commercial interests had led to the President abandoning his campaign pledge to link M F N to political and social change within China.

So in these respects, the Chinese market does appear to have structural power in the suggestion that diplomatic policy towards China is influenced by commercial decisions based on the need to secure competitive market access. Or more correctly, it is not the $\mathrm{C}$ hinese market as such, but a vision of what the $\mathrm{C}$ hinese market might become - the 'China D ream'. ${ }^{25}$

\section{Reconfiguring the global economy?}

A second source of conceptions of Chinese power comes from the impact of Chinese economic growth on the distribution of global finances and trade. The fact that at the end of 2003, China had U S\$403.3 bn worth of foreign currency reserves - second only to J apan - is clearly significant, 26 but what China does, or might do, with these reserves is even more significant. By buying $U S$ treasury bonds, China (and J apan) is effectively helping fund the U S debt. Thus, there is a fear that the $C$ hinese authorities hold the US economic fate in their hands. Should they suddenly sell all of these bonds, then economic logic suggests that this would lead to a rise in U S interest rates, throwing U S economic planning into turmoil. As Philip Segal argues, China has the power to 'crash the US government bond market'. ${ }^{27}$

But as Segal goes on to point out, while China might have the ability to cause a crash, a crash in the US would have a devastating impact on Chinese economic growth. With export growth the main engine of overall growth, and exports to the U S a significant proportion of this growth, then triggering higher interest rates and currency realignment in the US and the rest of the developed world would have a disastrous impact on China's own economic fortunes. A fter factoring in re-exports through Hong K ong and assessing the time-period from 1996 to 2003, then we can say that exports to OECD countries account for around 90 per cent of all exports, with roughly 30 per cent of all exports ending up in the U SA, around 26 per cent in

24 Select Committee on F oreign A ffairs, M inutes of Evidence, Examination of W itnesses, Tuesday 4 J uly 2000. Question 153.

25 J oe Studwell, The China Dream: The Quest for the Last Great Untapped Market on Earth (N ew Y ork: Grove Press, 2003).

26 This was after U S\$45 bn was spent on recapitalising state banks.

27 Philip Segal, 'How W ashington can be a hyper-power and a hyper-borrower: foreign buyers of U S bonds are banking on a stable U S consumer market'. Yale Global, 2 September 2003. 
J apan, and around 16 per cent in the EU .28 Looking at China from the outside can generate conceptions of Chinese power - but looked at from China out, the emphasis is more on China's dependence on the global economy. What the $\mathrm{F}$ ederal R eserve or the European Central Bank do to interest rates is as at least significant for the Chinese economy - and China's position in the global economy - than what the Chinese do to their own interest rates.

Similarly, while China's growth has had a significant impact on the global price of some commodities, the conception in China is of vulnerability and dependence rather than power. For example, in 2004, world steel prices rose dramatically, largely as a result of increased Chinese imports. In the longer term, oil could be even more significant. China became a net importer of oil in 1993, and:

Between 1993 and 2002, China's oil consumption surged from 2.9 million barrels per day (b/d) to 5.4 million b/d, while oil production only grew from 2.9 million b/d to 3.4 million b/d over the same period. In 2002, the share of oil consumption constituted by imports was 37 per cent. ${ }^{29}$

F or the rest of the world (and of course, for China itself) the question is what Chinese demand could do to global oil prices over a long period. F or China, the emphasis is more on insecurity as over half of oil imports come from OPEC countries, and nearly two-thirds pass through the straits of M alacca, which is not only under U S control, but where cases of piracy are far from uncommon. ${ }^{30}$

\section{External drivers of Chinese economic growth}

While growing imports into China are clearly important, it is the growth of exports from China that is causing even greater concern over the impact of Chinese economic growth:

F rom Tokyo to M ilan, from M exico City to Chicago, everyone is wondering whether China can continue to grow so fast and how their own jobs and businesses will be affected if it does. ${ }^{31}$

But while exports from China are impacting on jobs and growth in other countries, statistics used to support the idea of Chinese power are at best incomplete and at worst, totally misleading.

Take, for example, statistics over the size of China's trade surplus with the US, which are used to reinforce the argument that $C$ hinese growth is taking jobs from US workers. The problem here is that trade statistics are bilateral in nature, whilst global production and trade flows are not. The Chinese claim that if a good is exported from China to the U S, then the entire value is designated as being 'C hinese' irrespective of how much value has actually been located in China. So even if a U S\$10 export from China to the U S contains U S\$9 worth of components and raw materials imported into China from other nations, it will still show up as a U $\$ \$ 10$ trade deficit between

${ }^{28}$ F or more details of China's major trading partners, see Shaun Breslin, 'The Politics of Chinese Trade and the A sian F inancial Crises: Questioning the W isdom of Export-L ed G rowth', Third World Quarterly, 20:6 (1999), pp. 1179-1200.

29 Erica D owns, 'The Chinese Energy Security D ebate', The China Quarterly, 177 (2004), p. 23.

30 'U S "'attacks September 11" focusing China's oil security', Renmin ribao, 24 September 2001.

31 X avier Sala-I-M artin, Global Competitiveness Report Executive Summary (G eneva: W orld Economic F orum, 2003), p. 11. 
the U S and China. In reality, the value added within C hina of exports produced with foreign investment is extraordinarily low - the value of imports accounts for over 85 per cent of the value of foreign funded processed exports.

In reality, the majority of exports to C hina from other E ast A sian states are largely disguised exports to J apan, Europe and the U S. They are exports of machinery and components used in the production of goods that are subsequently exported out of China. A s such, it has been argued that "Japanese exports to East A sia "cause" significant inter-regional trade and ultimately exports to the U S by East A sia'. 32 The technological dependence of many producers and investors in East A sia as a whole, and China in particular, means that the balance of power over what is produced in E ast A sia has not dramatically shifted. Conversely, the US trade deficit with China is largely a disguised deficit with the region as a whole. R oss noted that while the U S trade deficit with China had increased between 1988 and 1997, the overall U S deficit with A sia as a whole had not grown considerably. ${ }^{33}$ W hat we see instead is a China acting as the manufacturing conduit through which the regional deficit is processed, with China running deficits with 'supplier' states in East A sia, and surpluses with 'demand' states in Europe and North A merica.

So the growth of Chinese exports is not only dependent on external demand, but it is also largely dependent on external supply. On one level, for the time being at least, Chinese industries are not major suppliers of foreign-invested export industries. The vast majority of the components and materials used to produce these exports are sourced from outside China. On another level, external supply is essential for financing China's export boom. F or H uang, the amount of F D I that has flooded into China should not be taken as a sign of Chinese power, but rather a sign of weakness reflecting the inability of domestic institutions to ration and distribute finances rationally. ${ }^{34}$ The focus here is not so much on the internal factors that $\mathrm{H}$ uang has dealt with in detail, but rather the extent to which China's important and significant position in the global political economy translates into power.

Foreign invested enterprises (FIEs) account for just over half of all Chinese exports - 55.81 per cent in 2003. If we add domestic Chinese producers who produce under contract for export using foreign components, then close to 70 per cent of all Chinese exports are made by or for foreign companies. The goods may be made in China, but in terms of who finances the production, and where the majority of the value of the goods resides, they are not just made by China.

A s with considerations of trade, simply looking at bilateral investment figures does not give a clear indication of who or what is the main source of investment into China. FDI from 'developed' states into China has increased in recent years. For example, in 2002, in the wake of China's WTO entry, for example, contracted investment by US investors increased by 25 per cent over $2001 .{ }^{35} \mathrm{~N}$ evertheless, a dominant theme throughout the literature on FDI in China is the significance of investment that comes from the rest of A sia in general, and from 'Chinese A sia' in

32 Takashi I sogai, H irofumi M orishita and R asmus R üffer, 'A nalysis of intra- and inter-regional trade in East A sia: comparative advantage structures and dynamic interdependency in trade flows'. Working Paper Series no. 02-E-1, Bank of J apan International D epartment, 2002, p. 3.

33 R obert S. R oss, 'W hy Our H ard-liners are Wrong', The National Interest (F all 1997), p. 48.

34 Y asheng Huang, Selling China: Foreign Direct Investment During the Reform Era (Cambridge: Cambridge U niversity Press, 2002).

35 M ark O'N eill, 'H ong K ong, Virgin I slands take top places in China investment stakes', South China Morning Post, 10 F ebruary 2003. 
particular. Houde and Lee calculate that between 1993 and 1998, Hong Kong provided over half of all investment into China, Taiwan nearly 8 per cent, and Singapore around 4.5 per cent. ${ }^{36}$ Similarly, Charles W olf calculates that 'two-thirds [of all investment has] come from "overseas" Chinese, especially overseas Chinese in Taiwan, Hong K ong, and Southeast A sia'. ${ }^{37}$

In recent years, investment from Latin A merica has increased dramatically, eclipsing FDI from both North A merica and Europe. A Imost all of this Latin A merican investment comes from the tax havens of the British Virgin I slands (now the second largest investor in C hina) and the Cayman I slands (now eighth). The very nature of this type of investment makes it difficult to know where it originates. Wu et al. point to the significance of $\mathrm{H}$ ong $\mathrm{K}$ ong companies, while other data, supported by interviews in the region, emphasises the role of Taiwanese firms - partly to take advantage of the tax regime, but also to bypass T aiwanese government restrictions on investment in the mainland.

This seems to suggest that it is the rest of A sia that is driving the supply of exports from China - that it is not a national effort, but a regional effort. But to really understand what is driving Chin's export growth, we need to move away from bilateral and even national conceptions of power and acknowledge the reality of transnational post-F ordist production networks. This reality is that:

capitalism today ... entails the detailed disaggregation of stages of production and consumption across national boundaries, under the organizational structure of densely networked firms or enterprises ${ }^{38}$

which leads us away from an emphasis on East A sia as the driver of Chinese export growth and highlights the significance of investment and production decisions that are made outside the region. The emphasis here is on Original Equipment $M$ anufacturing (OEM), the use of $\mathrm{H}$ ong $\mathrm{K}$ ong as an investment platform into China, and the ever growing importance of Contract $M$ anufacturing Enterprises (CM Es).

\section{OEM production and industry standards}

The term OEM was first used to refer to companies that put their own brand name on components produced by another company under a special agreement with the original manufacturer. Thus, for example, M itsumi is one of the world's biggest producers of cd-rom drives, rewriters and drivers that are used by numerous PC manufacturers. Whilst original OEM producers tended not to use the name of their components suppliers in the products, the situation has changed in some areas with the establishment of industrial standard leaders. In the computer industry, Intel has established a reputation as producing the best processors, and individual PC makers

${ }^{36} \mathrm{M}$ arie- $\mathrm{F}$ rance $\mathrm{H}$ oude and $\mathrm{H}$ ak- $\mathrm{L}$ oh $\mathrm{L} e e$, ' $M$ ain determinants and impacts of foreign direct investment on China's E conomy', OECD W orking Papers on International Investment, no. 2000/4 (2000), p. 7.

37 Charles Wolf, Straddling Economics and Politics: Cross-Cutting Issues in Asia, the United States, and the Global Economy (Santa M onica, CA : R and Corporation, 2002), p. 134.

${ }^{38} \mathrm{G}$ ary $\mathrm{G}$ ereffi, M iguel K orzeniewicz and R oberto Patricio K orzeniewicz, 'Introduction: G lobal Commodity Chains', in G ereffi and K orzeniewicz, Commodity Chains and Global Capitalism, p. 1. 
want to advertise the fact that they are using Intel components as a guarantee of the quality of their machines. Indeed, without the W indows operating system and Intel processors, it is all but impossible to gain a foothold in the PC market. As such, $M$ icrosoft and Intel can effectively control access to the PC market without producing PCs themselves through control of industry standards - a phenomenon that has been dubbed 'W intelism'. 39

OEM production is particularly important in IT industries, and in the production of hi-tech consumer goods - the fastest growing area of investment into China and of exports from China. Perhaps the most relevant example for this study is the T aiwanese computer industry. Borrus, ${ }^{40}$ Borrus and Zysman ${ }^{41}$ and Sturgeon ${ }^{42}$ all argue to different degrees that the US electronics companies altered their global strategy in the 1990s in response to challenges from A sia. Rather than simply competing with A sian producers, they instead created networks with A sian producers. The U S companies concentrated on developing the key components required for production through innovation, research and development and brand marketing, largely leaving the production of the computers themselves to companies in East A sia. They did not need to own these companies as control of industry standards in high-tech and high value-added sections of the production process ensured their continued dominance and profitability.

A round 70 per cent of all computer related goods produced by Taiwanese firms are based on OEM contracts with foreign firms - almost all from the U S and J apan. ${ }^{43}$ These Taiwanese computer companies themselves have embraced this changing manufacturing structure and located themselves as key links in the production chain. At a 'higher' level, they sign OEM agreements to produce computers using foreign technology and operating platforms - almost entirely with Japanese and US companies. At a 'lower' level, they have outsourced the low-tech and low value-added elements of production to maintain cost efficiency. ${ }^{44} \mathrm{~N}$ early three quarters of China's computer-related products are produced by Taiwanese companies, which are themselves dependent on OEM contracts with Japanese and U S companies. ${ }^{45} \mathrm{~A}$ s such, these Taiwanese-invested factories in China represent the end stage of a production process that spans the most industrialised global economies such as the USA and Japan, intermediate states such as Taiwan, and developing states like China. Bilateral investment figures will show Taiwanese investment in China. As the key components are sourced outside China, usually in Taiwan and Singapore and often exported to China via Hong Kong, one set of trade figures will show a Chinese deficit with regional states - but another set of trade figures will show Chinese exports to the major markets of the developed world, suggesting for some at least increased Chinese economic power in the global system.

\footnotetext{
39 M icheal Borrus and J ohn Zysman, 'W intelism and the changing terms of global competition: prototype of the future?', Working Paper $96 \mathrm{~b}$, Berkeley R oundtable on International E conomy, 1997.

40 M ichael Borrus, 'L eft for dead: A sian production networks and the revival of US electronics'. W orking Paper, Berkeley R oundtable on the International E conomy, 1995.

41 M icheal Borrus and J ohn Zysman, 'W intelism'.

42 Timothy Sturgeon, 'D oes manufacturing still matter? The organizational delinking of production from innovation'. Working Paper 92B, Berkeley R oundtable on International Economy, 1997.

${ }^{43} \mathrm{~K}$ atsuhiro Sasuga, Microregionalism and Governance in East Asia (L ondon: R outledge, 2005).

${ }^{44}$ Chen Shin-H ong, 'G lobal Production N etworks and Information Technology: The Case of Taiwan', Industry and Innovation, 9:3 (2002), pp. 249-65.

45 Sasuga, Microregionalism and Governance in East Asia.
} 


\section{Foreign indirect investment}

Extra-regional actors also have a disguised involvement in the Chinese economy as investment into China often takes place through subsidiary offices in Hong $\mathrm{K}$ ong. For example, Sanyo's business operations in China are managed and invested through Sanyo's subsidiary companies located in Hong Kong. Although sorting through the statistics is an inexact science, $M$ atsuzaki has estimated that about 80 per cent of J apanese F D I in H ong K ong is subsequently reinvested in G uangdong, appearing first as J apanese investment into $\mathrm{H}$ ong $\mathrm{K}$ ong, and subsequently as a $\mathrm{H}$ ong Kong investment into China. 46

It becomes even more difficult to calculate the real extent of non-Chinese investment in China when we consider the extent of sub-contracted FDI. Here, third country investors do not invest in China either directly or through regional offices, but instead subcontract production to investment and/or management companies within the East A sia region itself. Such investment has been a major el ement in non-A sian involvement in China in textiles, clothing and shoes, toys, and more recently, electronics.

F or example, the Pou-Chen ${ }^{47}$ company based in Taiwan produces 15 per cent of the world's sport shoes in its factories in China. But instead of bearing the Pou-Chen brand name, the shoes are made for Nike, Reebok, New Balance, A didas, Timberland, A sics, Puma, $\mathrm{H}$ i-Tec, L otto, LA Gear, M itre and others. Whilst Pou Chen is a special case given its global market share, consumers in the West can purchase goods across a range of areas which will carry a non-A sian brand name and the ' $M$ ade in C hina' stamp, but where bilateral figures will show an A sian investment in China. A nother type of subcontracting is where the third country company subcontracts to a regional intermediary, which then produces in China on a contract basis. In these cases, no investment will be recorded as the transactions are on a processing fee basis, even further disguising the original investors' involvement in the Chinese economy.

$M$ ajor investment companies such as the Swire $G$ roup and J ardine $M$ atheson have long acted as intermediaries between China and the global economy. Perhaps less well known are the plethora of $\mathrm{H}$ ong $\mathrm{K}$ ong owned companies such as $\mathrm{L} \mathrm{i}$ and $\mathrm{F}$ ung, which act as intermediaries in the global supply chain. M ore recently, Taiwanese companies have also developed such an intermediary role in accessing China through companies such as the above-mentioned $\mathrm{Pou}-\mathrm{C}$ hen, $\mathrm{H}$ on $\mathrm{H}$ ai and so on. ${ }^{48}$

There are three main reasons why these intermediary companies have established themselves as a link between foreign producers and China. First, R odrik has noted a tendency to subcontract to countries with poor labour standards rather than invest there directly. ${ }^{49}$ Second, the intermediary companies themsel ves market themselves as matchmakers with specialist expertise and specialist knowledge of China - technical, cultural

46 Y M atsuzaki, 'H on K on: tai Chu kyoten to shite no genjo', in K Ishihara (ed.), Chugoku Keizai no Kokusaika to Higashi Ajia (Tokyo: A jia K eizai K enkyusho, 1997), p. 160. Cited in Sasuga, Microregionalism and Governance in East Asia.

47 K nown as Bao Cheng in China.

48 Boy L uthje, 'Electronics Contract M anufacturing: G lobal Production and the International Division of L abor in the A ge of the Internet', Industry and Innovation, 9:3 (2002), pp. 227-47.

49 Dani Rodrik, Has Globalization Gone too Far? (Washington, D C: Institute for International Economics, 1997), p. 46. 
and linguistic. ${ }^{50}$ Third, many of these intermediary companies take responsibility for the entire production process, and not just the manufacturing element in China. This means that the original investing company does not need to run its own factories and employ permanent staff who will still need paying, or redundancy payments if demand falls. M uch easier to let the burden of employment fall on others instead, particularly if they are operating in economies with rather laxer employment conditions.

A $n$ increasing number of major multinational companies do not produce anything themselves anymore, leaving the production process to contractors whilst they concentrate on research and development and marketing. A lthough different scholars point to different features, ${ }^{51}$ they share a basic understanding that F ordist production processes based on horizontal integration have given way to vertical integration between core companies and their production affiliates, supplier and subcontractors.

Two key features are worth noting here. F irst, this vertical integration takes place across national boundaries, with different stages of the production process located in the most financially advantageous location. Second, the production process is often no longer controlled by the core company at all. R ather than operate through formal affiliates, production is placed in the hands of specialised companies. This is not a new phenomenon - major sports-wear companies such as $\mathrm{Nike}$ have long been corporations without factories. But Luthje argues that it is becoming ever more significant in global production, particularly in the IT industry. He points to the growing significance of five major Contract M anufacturing Enterprises (CM Es) of $\mathrm{N}$ orth A merican origin which lay a pivotal role in the production of consumer electronics - Solectron, Flextronics, $\mathrm{SCI}$, and Jabil Circuits from the USA, and Celestica from Canada. 52

A lthough the major CM Es are N orth A merican in origin, F lextronics invests in China through Singapore on behalf of $\mathrm{M}$ icrosoft, $\mathrm{M}$ otorola, Dell, Palm and Sony E rickson. In all these cases, the ' $M$ ade in China' brand will appear on the good - a good which carries a non-Chinese brand name produced by intra-A sian trade and investment, but which originated in the production and investment strategy of companies in the developed world, largely based on demand in markets in the developed world.

The prima facie evidence suggests that J apanese companies have been even more important than bilateral investment decisions suggest. U S companies have also been much more engaged with the $C$ hinese economy than the investment and trade figures suggest - albeit through third party actors. So despite the fact that there is concern in the US that China's growth is leading to the loss of jobs elsewhere, it is often companies in the US that are generating these job losses. In response to criticisms of China's trade regime from the U S, F oreign M inister Li Zhaoxing (2003) argued that exports from China were:

50 Gordon $\mathrm{H}$ anson and R obert F eenstra, 'Intermediaries in Entrepôt Trade: Hong K ong Re-Exports of Chinese Goods', Working Paper 8088, N BER, 2001.

51 For a description and analysis of the various terms used and how they correspond with each other, see Suzanne Berger, Constanze K urz, Timothy Sturgeon, U Irich V oskamp, V olker W ittke, 'G lobalization, Production N etworks, and $\mathrm{N}$ ational $\mathrm{M}$ odels of Capitalism: On the Possibilities of $\mathrm{N}$ ew Productive Systems and Institutional Diversity in an Enlarging Europe', SOFI-M itteilungen no. 29, U niversity of G öttingen, 2001.

52 Luthje, 'Electronics Contract M anufacturing'. 
not only benefiting the average A merican consumers but also helping U S industrial restructuring and upgrading. ... more than half of the Chinese exports to the US are produced by foreign-funded enterprises in China, mostly U S companies. ${ }^{53}$

But trying to identify the nationality of investment is often a misguided endeavour. If we think of those sectors where the ' $M$ ade in China' stamp is now commonplace throughout the world, then it is largely corporate decisions driven by understandings of market behaviour in core economies that have propelled Chinese exports. So in many respects, economic power lies in the hands of non-state actors in deterritorialised transnational production networks that have the power to decide, as Engels put it, 'what is produced, how it is produced, and how the products are exchanged'.

\section{States and markets}

A Ithough I have argued that real power is in the hands of non-state actors, this does not mean that I think that the state is irrelevant. Chinese government actors at the national and local level have done an enormous amount to facilitate private investment flows into C hina. It is not a case of trying to decide who has power, states or markets, but analysing the relationship between the two. If we think in terms of the state as a unitary actor rationally pursuing the national interest in a game of mercantilist competition, then it is difficult to reconcile an understanding of state power with notions of power located in transnational production networks. But if we think of the state as representing a subset of interests in the domestic sphere - either from a liberal or neo-G ramscian perspective - then the connection is much easier to make.

Neoliberalism - as promoted by purposive state actors and international organisations - does not just exist in a political void. It is predicated on political and ideological preferences and, if not promoted by, certainly facilitated by the decisions of governments and international organisations (which also represent a subset of interests at the global level). N ational and local governments across the world have implemented numerous policy initiatives to facilitate increased transnational economic relationships that have created the environment within which non-state actors can manoeuvre. F or example, while Susan Strange asserted that transnational corporations (TNCs) are key actors in the promotion of globalised production, she argued that:

this has not happened entirely by accident. The shift from state authority to market authority has been in large part the result of state policies. It was not that the TNC s stole or purloined power from the government of states. It was handed to them on a plate- and, moreover, for 'reasons of state'. ${ }^{54}$

Strange went on to argue that even the US government could not contain the forces that it unleashed, and that even the world's most powerful government finds its actions constrained by the actions of TN Cs. But this should not obscure the fact that the original liberalisation of the economic structure was based on political choice and

53 Li Zhaoxing, 'Speech at U S-China Business Council', 23 September 2003, 〈http://www.fmprc.gov.cn/ eng/wjdt/zyjh/t26295.htm>.

54 Susan Strange, The Retreat of the State (Cambridge: Cambridge U niversity Press, 1996), pp. 44-5. 
decisions of governments that served the interests of a subset of national actors. As Underhill argues, we should not conceive of markets and political authorities as contending and/or separate forces, but rather as part of an 'integrated ensemble of governance'. 55

In promoting economic reform, Chinese elites never intended to loosen party control - on the contrary, reform was the best way of ensuring the party's grip on power. R ecognising the popular loss in faith in the C CP in the wake of the horrors of the Cultural R evolution, D eng X iaoping and others rejected mass campaigns and political programmes based on ideological indoctrination as a means of building popular support for the party. A longside nationalism, legitimacy is based on providing political and social stability and through performance - with performance largely defined in terms of economic success. Thus, continued C CP rule provides the political stability and personal safety which disappeared in other communist party states where political reform led to the collapse of communist party control. Crucially, the stability provided by party rule is promoted by the party as being the prerequisite for economic growth and prosperity. What has emerged is an unwritten social contract between the party and the people whereby the people do not compete with the party for political power as long as the party looks after their economic fortunes.

The importance of economic performance as a key basis of legitimacy placed an emphasis on rapid capital accumulation. As with many other state developing countries, the best way of ensuring this rapid capital accumulation and economic growth increasingly came to be seen as insertion into the capitalist global economy. There is an ideational acceptance, albeit not necessarily explicitly stated, that dependence on the capitalist global economy is the best or at least the quickest way of promoting economic growth.

So the location of parts of the Chinese economy into the global division of labour and production was a result of specific and deliberate government policy. It required legal changes to permit foreign investment and ownership and the creation of a publicly funded physical infrastructure to facilitate the flow of commodities. $\mathrm{N}$ ational and local governments have also provided an array of other financial incentives to attract foreign investment to produce exports, both in competition with other developing states and with other parts of China.

These governmental decisions and policies have been highly successful when they have coincided with the interests of mobile transnational capital. When they have not coincided, then government policy has had to change. In their analysis of Taiwanese investment in the Xiamen SEZ, Qi and Howe (1995) show how the Xiamen authorities originally concentrated on attracting electronics manufacturers, and designed their local development strategy accordingly. H owever, T aiwanese investors had different priorities, and instead brought in more and more chemicals producers and 'faced with this divergence, the $X$ iamen authorities apparently abandoned their original goal and declared petrochemicals to be their new "investment emphasis" ".56 A similar process occurred in Shenzhen where the local leadership tried to restructure

55 G eoffrey U nderhill, 'Conceptualising the Changing G lobal Order', in R ichard Stubbs and G eoffrey Underhill, Political Economy and the Changing Global Order (Oxford: Oxford U niversity Press, 2000), p. 4.

56 Qi L ou and Christopher Howe, 'D irect Investment and Economic Integration in the A sia Pacific: The Case of Taiwanese Investment in Xiamen', in David Shambaugh (ed.), Greater China: The Next Superpower? (Oxford: Oxford U niversity Press, 1995), pp. 94-117. 
the local economy by imposing disincentives for processing industries and component assembly. Whilst these industries did indeed decline, the high-tech and finance investments that Shenzhen were hoping to attract were not forthcoming. A s a result, the local authority reversed its policy, and reintroduced a number of incentives to lure back the processing and component assembly investments. ${ }^{57} \mathrm{~W}$ hen the government in Beijing removed tax exemptions on imported goods used in foreign funded enterprises in 1996, FDI declined to such an extent that the government back-tracked and reintroduced tax exemptions on such imports from 1st J anuary 1998. And the much vaunted 'look W est' strategy aimed at encouraging more investment into non-coastal areas has largely failed to pull in significant new investors, raising questions over the Chinese government's ability to shape the domestic spatial distribution of growth.

\section{R ethinking $\mathrm{C}$ hinese economic power}

So in terms of the numerous policies designed to facilitate engagement with the capitalist global economy, the Chinese government does have considerable power. L ocating parts of the Chinese economy as a low cost manufacturing site in global production chains might be a strange sort of power - particularly, if US trade union groups are to believed, it entails the repression of workers' rights. But it is a state strategy that has had a considerable impact.

Unlike Japan a generation ago, which reinvented manufacturing through quality and continuous improvement, China is deinventing it by removing capital and reintroducing manual skill and handling on the plant floor. China's far lower cost of not only production workers but plant technicians, accountants and managers allows U.S. companies to rethink everything from how the product and its parts are designed to how they are made and tested. ${ }^{58}$

Decisions made by Chinese political elites about the manner in which China re-engaged with the global economy has led to a reconfiguration of the regional economy. While the investment-trade nexus in A sia is not a zero-sum game, China is competing with other export-oriented states for foreign investment, and competed with the same states for access to the key lucrative markets of the U S, J apan and the EU. This process has led the New York Times to argue that:

China is grabbing much of the new foreign investment in A sia, leaving its once-glittering neighbors - Thailand, South K orea, Singapore - with crumbs... Some A sian officials say they fear that Southeast A sia will be relegated to the role of supplier of food and raw materials to China in exchange for cheap manufactured goods. 59

One of the ways in which China is 'grabbing' this investment was by maintaining a pegged and undervalued exchange rate with the dollar.60 Indeed, for some observers, the 1994 devaluation of the R enminbi was a pivotal moment in the reorganisation of

57 China N ews Service, 6 D ecember 1995.

58 Thomas H out and J ean Lebreton, 'The real contest between A merica and China', The Asian Wall Street Journal, 16 September 2003.

${ }^{59}$ Cited in Friedrich Wu, Poa Tiong Siaw, $\mathrm{Y}$ eo $\mathrm{H}$ an Sia and Puah K ok K eong, 'F oreign Direct Investments to China and Southeast A sia: H as A sean Been Losing Out?' Economic Survey of Singapore (Third Quarter, 2002), p. 96.

60 The peg was dropped in July 2005 when the value of the R enminbi was allowed partial freedom to float against a basket of currencies. 
the regional economy that resulted in the financial crises of 1997. W hilst this is a contested analysis, in politics, perceptions are often more important than reality, and whatever the reality of this debated impact of $C$ hinese devaluation on regional states really was, there remains a perception in the region that China's re-engagement with the global economy has had a detrimental impact on its neighbours' economies. With China's entry into the WTO, this impact is expected to grow as investment is diverted from South East A sia to China. ${ }^{61} \mathrm{~F}$ orecasts from the World Bank suggest that the closer a state's export profile to that of China, the more that state is expected to lose, with workers in the textile and apparel sectors in the region predicted to lose most. 62

Throughout A sia, this conception of $C$ hina as a super-competitor is informing not only media debates, but also official policy. Lee K wan $\mathrm{Y}$ ew has famously described the economic relationship between Singapore and China as an 'elephant on one side and a mouse on the other', arguing that China is no longer interesting in promoting its regional ambitions through military means, but rather 'The emphasis is on expanding their influence through the economy'. M alaysia's M ahathir M ohamad has aired his concern that 'There's not much capital going around. W hatever there is gets sucked in by China'63 with claims that 16,000 jobs were lost in Penang alone in 2002 as major hi-tech producers move capacity to China. ${ }^{64}$

It is difficult to compete with China, but it is possible to supply China. This has long been the case for producers of components and materials used in Chinese export industries in the more developed regional economies - South K orea, Japan, Taiwan, $\mathrm{H}$ ong $\mathrm{K}$ ong and Singapore. A nd although politicians and academics in these states warn of the danger of dependence on the Chinese economy, it is also the case that Chinese growth - built as it is on the growth of exports - is in itself dependent on foreign investment from these regional states and elsewhere.

Supplying China is increasingly not only restructuring the regional economy, but also the economies of individual regional states. For example both the nature and destination of Thai exports has changed:

several labor-intensive manufactured exports shrunk. ... aggregate exports to the U nited States, E urope and J apan combined, comprising more than half of all Thai exports, stagnated, even as China expanded its share in those markets. Thailand successfully tapped into the expanding Chinese market. Thai exports to China grew by a blistering 24 percent [in 2002], comprising mostly of manufactures and relatively more technology-intensive products. 65

Similarly, Malaysian exports to China have come to be dominated by electrical components, chemicals, machinery parts, and petroleum and Indonesia's by processed oil and rubber - all materials or components that are in high demand in China's export-oriented industries.

${ }^{61}$ Elissa Braunstein and G erald Epstein, 'Bargaining power and foreign direct investment in China: can 1.3 billion consumers tame the multinationals?' W orking Papers 2002-13, Center for E conomic Policy A nalysis, N ew School U niversity, 2002.

62 Elena Ianchovichina, Sethaput Suthiwart-N arueput and M in Zhao (2004), 'R egional Impact of China's WTO A ccession', in K athie K rumm and Homi K haras (eds.), East Asia Integrates: A Trade Policy Agenda for Shared Growth (Washington, D C: W orld Bank, 2004), pp. 57-78.

${ }^{63}$ Clay Chandler, 'Coping with China: as China becomes the workshop of the world, where does that leave the rest of A sia?', Fortune, 16 J anuary 2003.

${ }^{64}$ Erik Eckholm with J oseph K ahn, 'A sia worries about growth of China's economic power', New York Times, 24 N ovember 2002.

65 W orld Bank, 'Thailand E conomic M onitor, M ay 2003', 〈http://www.worldbank.or.th/monitor/ economic/2003may.shtml〉. 
A key question for policymakers in Indonesia and the Philippines in particular the two states with the closest export profile to China's - is whether the domestic political economy can be restructured to cope with this impact from China? D espite the growth of Indonesian exports to China in the supply chain, a World Bank study on the impact of China's WTO membership on the region found that ' 23 per cent of Indonesia's exports are potentially at risk' from Chinese competition. 66 The impact on the Philippines could be even more damaging:

The Philippines' ability to move up the value chain and capture more benefits from China's accession will depend on what strategy the country adopts. $\mathrm{M}$ any of the sectors that will suffer from China's WTO accession are intensive in the use of unskilled labor, while those that will expand are more intensive in land or skilled labor. Wages of unskilled workers may well come under pressure. ${ }^{67}$

This points to the importance of disaggregating national perspectives. The biggest overall impact might be on Indonesia and the Philippines, but the jobs lost by workers in Japan, $\mathrm{H}$ ong $\mathrm{K}$ ong and South $\mathrm{K}$ orea as companies that have moved production to China are just as real. And even where countries lose in aggregate terms, companies and individuals have maintained, if not increased, market share and profits by moving production to China.

Thus, there is concern in Hong K ong, Japan and South K orea that the domestic economies are becoming hollowed out as investors move their manufacturing capacity to China. In Taiwan there is a strong concern that economic dependence on the mainland will increase China's ability to force its will on Taiwan in political spheres. In an attempt to reduce this dependence, in 1993, Taiwan's economic minister, Chiang Pin-K ung, announced a ' $G$ o South' policy to encourage investors to look at South East Asia rather than China. A similar policy called 'N o H aste, Be Patient' was introduced in 1996 in an attempt to slow the rate of investment on the mainland. $\mathrm{N}$ either of these strategies have had a significant influence on the flow of investment from Taiwan to the PRC - quite simply because producing in China makes more economic sense than either producing at home, or in other regional states. As such, the strategic decisions of the Taiwanese government have been undermined by the commercial decisions of Taiwanese based non-state actors.

The political concerns of governments and the commercial interests of private economic actors frequently diverge. W ith the exception of 2001, Taiwan's G DP has continued to grow as investment and manufacturing have moved to China since the first year of large-scale investment in 1993. But at the same time, the unemployment rate has continued to rise from 1.45 per cent in 1993 to 5.17 per cent in 2002 before dropping back to just under 5 per cent in 2003. Similarly, with the exception of 1998, H ong K ong's GDP has also continued to grow. A growth rate of over 3 per cent in 2003 might be modest by historical comparison, but is still a growth rate that managers of most economies in the developed world would be more than pleased with. But as with Taiwan, unemployment rates have also risen, from 2 per cent in 1993 to almost 8 per cent in 2003. As the goods produced in China are largely destined for markets in $\mathrm{N}$ orth A merica and E urope, the lack of domestic demand in $\mathrm{H}$ ong $\mathrm{K}$ ong and Taiwan is not particularly important. Indeed, growing domestic unemployment has kept interest rates low in $\mathrm{H}$ ong $\mathrm{K}$ ong and Taiwan, making capital

${ }^{66}$ I anchovichina, Sethaput and M in, 'R egional Impact of China's WTO A ccession', p. 69.

67 Ibid., p. 71. 
for investment into China very cheap. As such, 'jobless growth' actually serves the interests of investors extremely well.

$\mathrm{N}$ or is this just an $\mathrm{A}$ sian issue. In a petition to President Bush asking for action against $\mathrm{Chinese}$ imports, the $\mathrm{AFL}-\mathrm{ClO}$ and the Industrial $\mathrm{U}$ nion Council argued that more than 727,000 U S jobs had been lost as a direct result of labour abuses in China. If these labour abuses were halted, they argued that the price of Chinese manufactured goods would rise by between 12 and 77 per cent. Scan newspapers from across the world and it is easy to find stories of companies moving production to China, usually citing the fact that competitors have already gone and they cannot compete if they don't follow. M oving to China keeps prices down for consumers, and maintains, if not increases, profits for the companies involved, but it also leads to job losses for workers, in some cases leading to jobless growth. The implications of China's insertion into global production networks for individuals vary greatly depending on the individual's own position in those global production networks.

\section{Conclusions}

This article has attempted to show that while China is clearly important and significant for the global economy in general, and the East A sian regional economy in particular, the nature of Chinese economic power is not as large as perhaps the headline figures imply. The fact that one of the world's biggest economies is still a relatively poor economy is an important challenge, but one that leads to a different set of policy considerations than notions of China as an economic superpower.

A s Payne and G amble have argued, power in the global political economy should not just be thought of in terms of the power of states. In addition, analysts and indeed governments need to recognise the 'structural power of internationally mobile capital', ${ }^{68} \mathrm{~F}$ or G ill, the desire to attract and retain investment has a disciplining impact on policymakers, as they adjust policy to meet the needs of this mobile capital.69 Thus, as Cox has argued, the hegemony of neoliberalism as an economic model results in state actors playing the role of adjusting the domestic political economy to the requirements of mobile transnational capital-although this often coincides with attempts to protect vulnerable domestic groups - to moderate neoliberal globalisation. ${ }^{70}$ State policy, in China and elsewhere, both reflects and facilitates the economic power of non-state actors.

To be fair, this analysis of $C$ hinese economic power, with its emphasis on low cost production in a global division of labour, is rather static in nature. Other countries have started off as low cost manufacturing sites and subsequently upgraded to higher and more profitable stages of production. It is not inevitable that China will follow a similar developmental trajectory as countries like J apan, South K orea and T aiwan, but we should certainly not rule out a similar process occurring in $\mathrm{China}$. If it does, then the arguments in this article will need to be considerably revised.

${ }^{68}$ A nthony Payne and Andrew Gamble, 'Introduction: The Political Economy of R egionalism and W orld Order', in A ndrew Gamble and Tony Payne (eds.), Regionalism and World Order (Basingstoke: M acmillan, 1996), p. 15.

${ }^{69}$ Steven Gill, 'G lobalisation, $M$ arket Civilisation, and Disciplinary N eoliberalism', Millennium, 24:3 (1995), pp. 399-423.

70 R obert Cox, 'Civil Society at the Turn of the M illennium: Prospects for an A Iternative', Review of International Studies, 25:1 (1999), p. 12. 